\title{
Qiang WANG
}

A Monograph of the Genus Microtoena (Lamiaceae) 
This book was originally published by Science Press, (C) Science Press, 2018.

\author{
Qiang WANG \\ State Key Laboratory of Systematic and Evolutionary Botany, Institute of Botany, \\ Chinese Academy of Sciences, Beijing
}

Responsible Editors: Jing WANG and Haiguang WANG

Printed in France

EDP Sciences - ISBN(print): 978-2-7598-2528-8 - ISBN(ebook): 978-2-7598-2529-5

\begin{abstract}
All rights relative to translation, adaptation and reproduction by any means whatsoever are reserved, worldwide. In accordance with the terms of paragraphs 2 and 3 of Article 41 of the French Act dated March 11, 1957, "copies or reproductions reserved strictly for private use and not intended for collective use" and, on the other hand, analyses and short quotations for example or illustrative purposes, are allowed. Otherwise, "any representation or reproduction - whether in full or in part - without the consent of the author or of his successors or assigns, is unlawful" (Article 40, paragraph 1). Any representation or reproduction, by any means whatsoever, will therefore be deemed an infringement of copyright punishable under Articles 425 and following of the French Penal Code.
\end{abstract}

The printed edition is not for sale in mainland China. Customers in mainland China please order the print book from Science Press. ISBN of the China edition: Science Press ISBN: 978-7-03-056235-7

(C) Science Press, EDP Sciences, 2020 


\section{DEDICATION}

Dedicated to the 'father' of Microtoena and ex-director (1905-1922) of the Royal Botanic Gardens, Kew:

Dr. David Prain 
